\title{
CENTAUREA RUTHENICA LAM. (ASTERACEAE DUMORT.) IN THE FLORA OF THE REPUBLIC OF MOLDOVA
}

\author{
Pavel PÎNZARU ${ }^{1,2}$ \\ 1 “Alexandru Ciubotaru” National Botanical Garden (Institute), Chișinău - Republic of Moldova. \\ ${ }^{2}$ Tiraspol State University, Chișinău - Republic of Moldova. \\ E-mail: p_panzaru@yahoo.it
}

\begin{abstract}
The presence of Centaurea ruthenica Lam. in the flora of the Republic of Moldova was indicated by SCHMALHAUSEN $(1886,1897)$, near the village of Rascov, on the left bank of the Dniester River. This summer, the author has found this species near the village of Tipova, Rezina district, on the right bank of the Dniester River. This article presents the morphological description of the species, its biological and ecological features under the local conditions. It has been proposed to include Centaurea ruthenica Lam. in the Red Book of the Republic of Moldova, in the Critically Endangered (CR) category.
\end{abstract}

Key words: Centaurea ruthenica Lam., Asteraceae Dumort., morphological description, biological and ecological features, Republic of Moldova.

\section{Introduction}

Centaurea ruthenica Lam. [=Rhaponticoides ruthenica (Lam.) M. V. Agab. et Greuter] is a hemicryptophytic, xerophytic, heliophyte occurring in the Balkans, central Europe (Transylvania region in Romania), East Europe (southern part), the Caucasus, Western Siberia and Central Asia [TZVELEV, 1963; DOSTÁL, 1976; CZEREPANOV, 1994; DOBROCZAJEVA, 1999; PLANTARIUM, 2007-2021; AGHABABYAN, 2008; NEGREAN \& DIHORU, 2009, SÂRBU \& al. 2013; CWG, 2021], considered a rare Eurasian (continental) species, included in the Red Book of Romania, in the Critically Endangered (CR) category [NEGREAN \& DIHORU, 2009], and some regions of Russia and Ukraine [PLANTARIUM, 2007-2021].

The presence of the species Centaurea ruthenica Lam. in the village of Rascov, on the left bank of the Dniester River was indicated by SCHMALHAUSEN (1886, 1897), in other bibliographical sources it is missing. In June, this year, it was found near the village of T,ipova, Lalova commune, Rezina district.

This article presents the morphological description of the species, its biological and ecological features under the local conditions.

\section{Materials and methods}

The plants of Centaurea ruthenica Lam. were collected by the author on June 27, 2021, the exsiccatae are kept in the Herbarium of the "Alexandru Ciubotaru" National Botanical Garden (Institute), in the Herbarium of “Anastasie Fătu” Botanical Garden of Iași [IAGB 47715] and in the author's own Herbarium, donated to the State University of Tiraspol (Kishinev). Mature achenes were collected on July 27, 2021, which will be cultivated under ex situ conditions, for multiplication and reintroduction into characteristic natural habitats of the species. 
The species was determined according to the classical comparative-morphological method, using the illustrated guide for species determination "Vascular plants of Romania" [SÂRBU \& al. 2013]. The evaluation and the determination of the conservation category was performed according to the criteria adopted by the International Union for Conservation of Nature [IUCN, 2001, 2003].

\section{Results and discussions}

As a result of the continuation of the floristic studies on the cliffs vegetation in the Republic of Moldova, the species Centaurea ruthenica Lam. was detected for the first time on the right bank of the Dniester River, near the village of Tipova, Rezina district.

Centaurea ruthenica Lam. 1785, Encycl. Méth. Bot. 1: 663; Schmalhausen, 1886, Fl. Jugo-Zap. Ross.: 329, id. 1897, Fl. Sred., Jug. Ross., Kryma, Sev. Kavkaza 2: 120; Tzvelev, 1963, Fl. URSS, 28:380; Dostál, 1976, Fl. Europ. 4: 263; Czerepanov, 1994, Fl. partis europ. URSS, 7: 270; Dobroczajeva, 1999, Opred. Vysch. Rast. Ukr., ed. 2: 355; Sârbu, Ștefan \& Oprea, 2013, Pl. Vasc. România: 854. - Rhaponticoides ruthenica (Lam.) M. V. Agab. et Greuter, 2003, Willdenowia, 33: 61; Aghababyan, 2008, Caucas. fl. consp. 3 (1): 299. Centauree rusească. Star thistle - Figure 1-3.
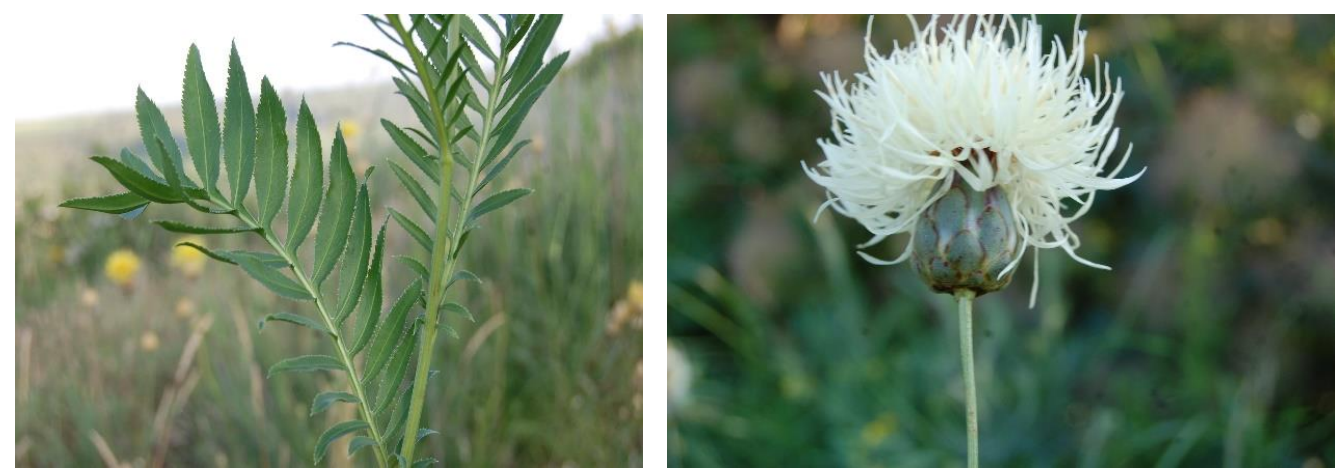

Figure 1. Centaurea ruthenica Lam., village of Țipova, Rezina district, 27.06.2021

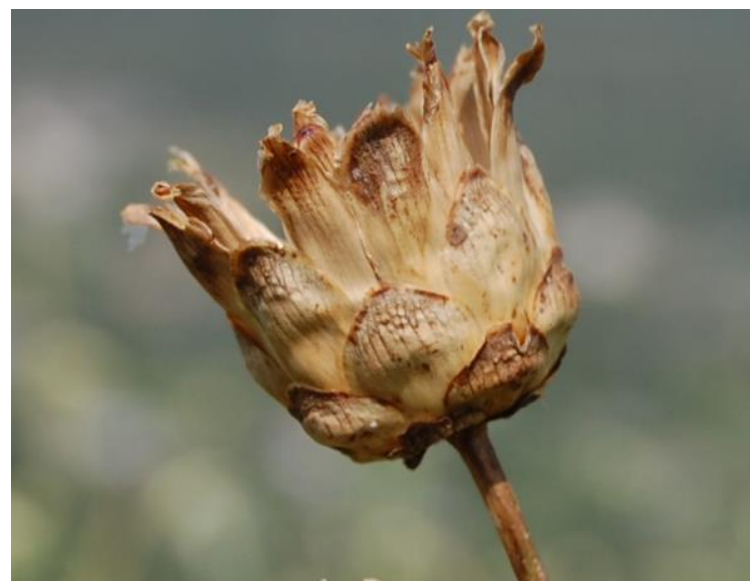

Figure 2. Centaurea ruthenica Lam. - involucre, 27.07.2021 
The plant is glabrous. Thickened rhizome, with 1-3 stems 100-120 (145) cm tall, simple or slightly branched at the top. The leaves are ovate-elongated, pinnatisect, with lanceolate segments, with toothed margins: the lower ones up to $25 \mathrm{~cm}$ long and up to $10 \mathrm{~cm}$ wide in the middle, with a 3-5 cm long petiole; the upper ones - gradually smaller, subsessile to sessile. The inflorescences are flower heads, grouped by $2-3$, terminal, $5-6 \mathrm{~cm}$ in diameter. The involucre is $2-2.5 \mathrm{~cm}$ in diameter, the outer and middle involucral bracts - wide-ovate, green during flowering, without appendices, with scarious margin, the inner ones - lanceolate, membranous at the tip. The flowers are pale-yellow: the external ones - sterile, $37 \mathrm{~mm}$ long, with a $12 \mathrm{~mm}$ long tube, laciniae grouped by 5 , long $25 \mathrm{~mm}$ and $1 \mathrm{~mm}$ wide; the internal flowers - fertile, smaller, $26 \mathrm{~mm}$ long, with $19 \mathrm{~mm}$ long tube, with 5 laciniae, $7 \mathrm{~mm}$ long, filiform. The stamens are slightly shorter than the laciniae of the corolla. The style is protruding, $6 \mathrm{~mm}$ longer than the corolla. The achenes are 6-7 mm long, slightly 4-edged, dark brown. The setae of the pappus are simple, unequal, up to 3-4 $\mathrm{mm}$ long, brown.

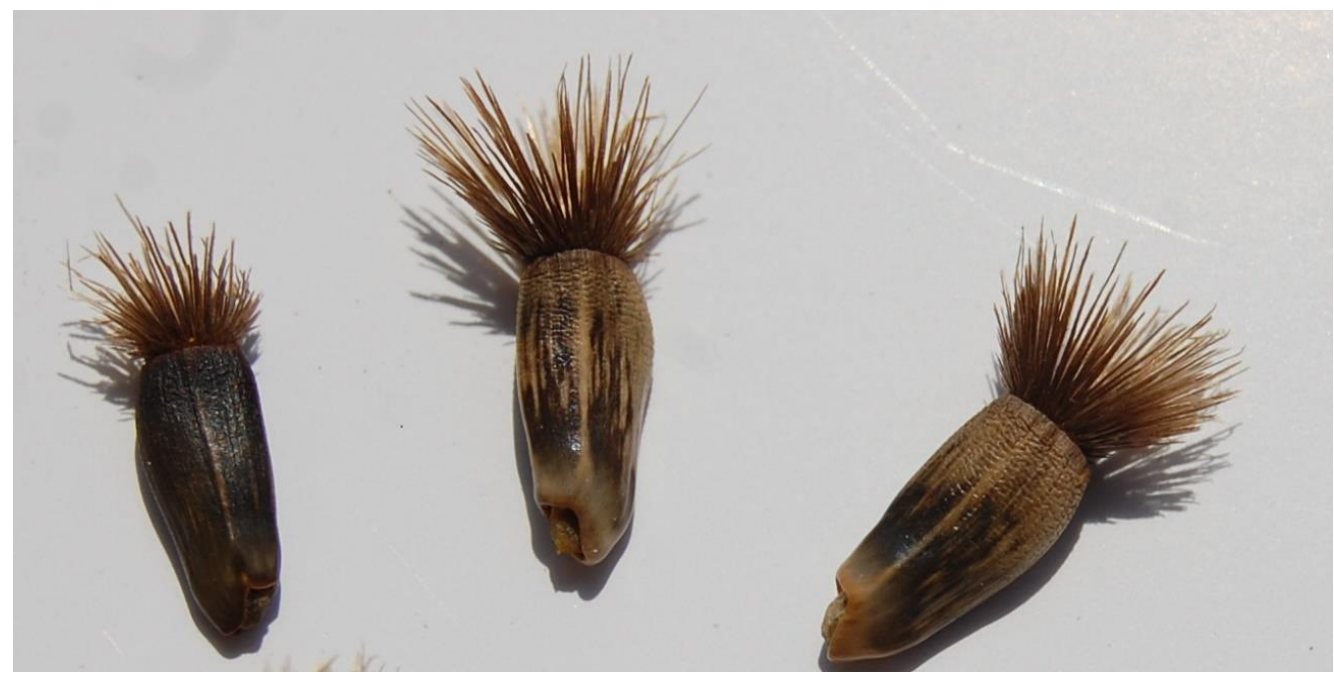

Figure 3. Achenes of Centaurea ruthenica Lam., 27.07.2021

Biological and ecological characteristics. Perennial hemicryptophyte, blooms in JuneJuly (beginning), the dissemination occurs at the end of July - beginning of August. $2 n=30$. The species is xerophytic, calcicole. In the Republic of Moldova, it occurs sporadically on rendzina soils, formed on limestone bedrock of Middle Sarmatian age. Altitude 140-143 m. It was found on east-facing slopes, with the inclination of $35^{\circ}-40^{\circ}$. The general coverage of the herbaceous layer vary between 80 and $100 \%$. In the vertical structure of the phytocoenoses, 3 layers are distinguished. 


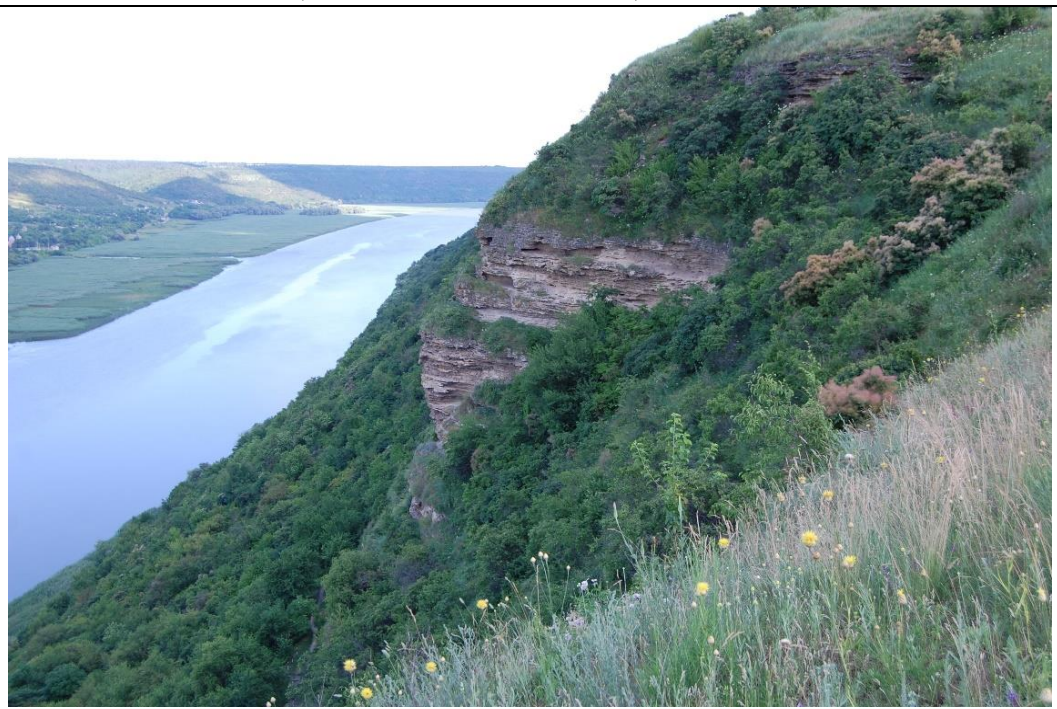

Figure 4. Centaurea ruthenica Lam. growing on a slope of the Dniester valley, village of Țipova, Rezina distict, 27.06.2021

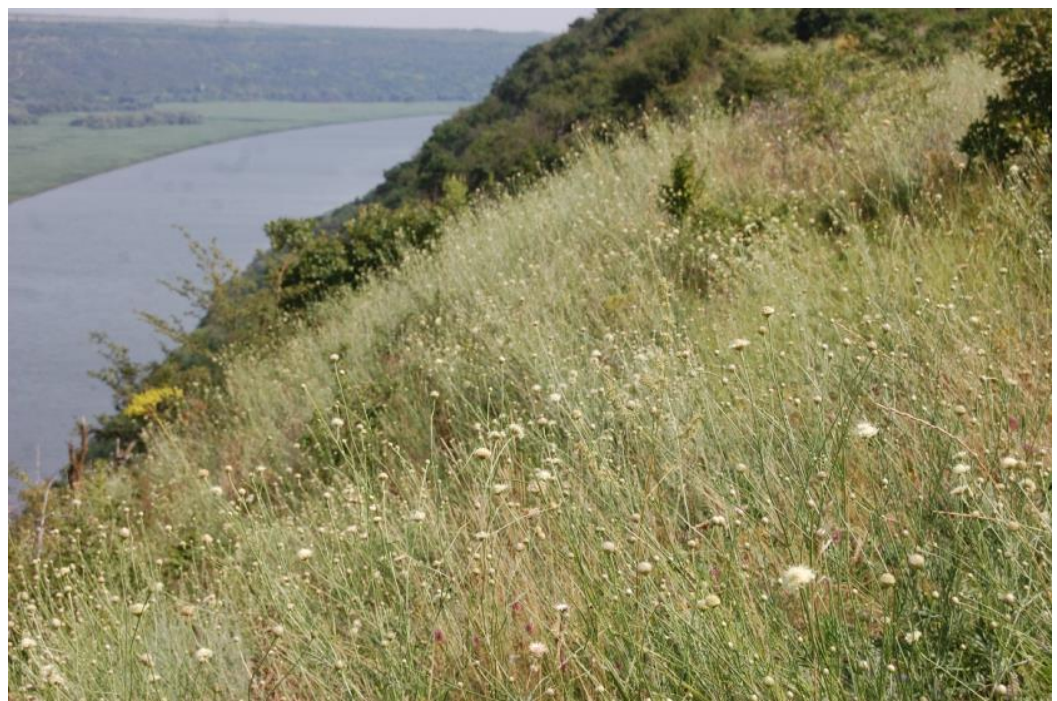

Figure 5. The habitat of Centaurea ruthenica Lam. in the upper part of the cliff

The upper layer, 80-120 (145) cm high, consists of: Agropyron cristatum (L.) Gaertn., Artemisia campestris L., Asparagus officinalis L., Asparagus verticillatus L., Bromus inermis Leys., Bupleurum falcatum L., Campanula rapunculoides L., Centaurea orientalis L., Centaurea ruthenica Lam., Elymus repens (L.) Nevski, Erysimum cuspidatum (M. Bieb.) DC., Hieracium virosum Pall., Isatis tinctoria L., Jurinea ledebourii Bunge, Melica transsilvanica Schur, Melilotus officinalis (L.) Pall., Scabiosa ochroleuca L., Serratula radiata (Waldst. \& Kit.) M. Bieb., Sisymbrium loeselii L., Stipa capillata L., Tanacetum corymbosum (L.) Sch. 
Bip., Thalictrum minus L., Valeriana collina Wallr., Verbascum phoeniceum L., Vincetoxicum hirundinaria Medik.

The middle layer, 30-60 cm high, consists of: Allium flavum L., Allium paniculatum L., Amygdalus nana L., Bromus squarrosus L., Camelina microcarpa Andrz., Cerinthe minor L., Euphorbia agraria M. Bieb., Festuca valesiaca Schleich. ex Gaudin, Lappula patula (Lehm.) Gürke, Marrubium peregrinum L., Medicago falcata L., Melampyrum arvense L., Nigella arvensis L., Odontarrhena muralis (Waldst. \& Kit.) Endl., Poa compressa L., Papaver stevenianum Mikheev, Reseda lutea L., Salvia nemorosa L., Securigera varia (L.) Lassen, Sedum maximum Suter, Silene csereii Baumg., Stachis recta L., Veronica spicata L., Xeranthemum annuum $\mathrm{L}$.

In the lower layer, up to $\pm 20 \mathrm{~cm}$, the following species grow: Alyssum alyssoides (L.) L., Arenaria serpyllifolia L., Aurinia saxatilis (L.) Desv., Clinopodium acinos (L.) Kuntze, Iris pumila L., Poa bulbosa L., Sedum acre L., Teucrium chamaedrys L., Teucrium capitatum L., Veronica prostrata L., Vinca herbacea Waldst. \& Kit.

Quantitative aspect. It grows sporadically on an area of about $400 \mathrm{~m}^{2}$, the only population detected consists of about 80 mature plants. Not all flower heads produce mature achenes, 1-5 (15) achenes reach maturity in one flower head.

Conservation status. Territorially protected in the "Țipova" Landscape Reserve.

Conservation measures. Inclusion in the List of species protected by the state and in the Red Book of the Republic of Moldova, in the Critically Endangered (CR) category; monitoring the condition of the existing population; $e x$-situ multiplication of the species and its repatriation into its characteristic natural habitats.

Local distribution. It has been found in the village of Ţipova in Lalova commune, Rezina district, and its presence in Rașcov commune in Camenca district (probably extinct) was indicated by SCHMALHAUSEN $(1886,1897)$.

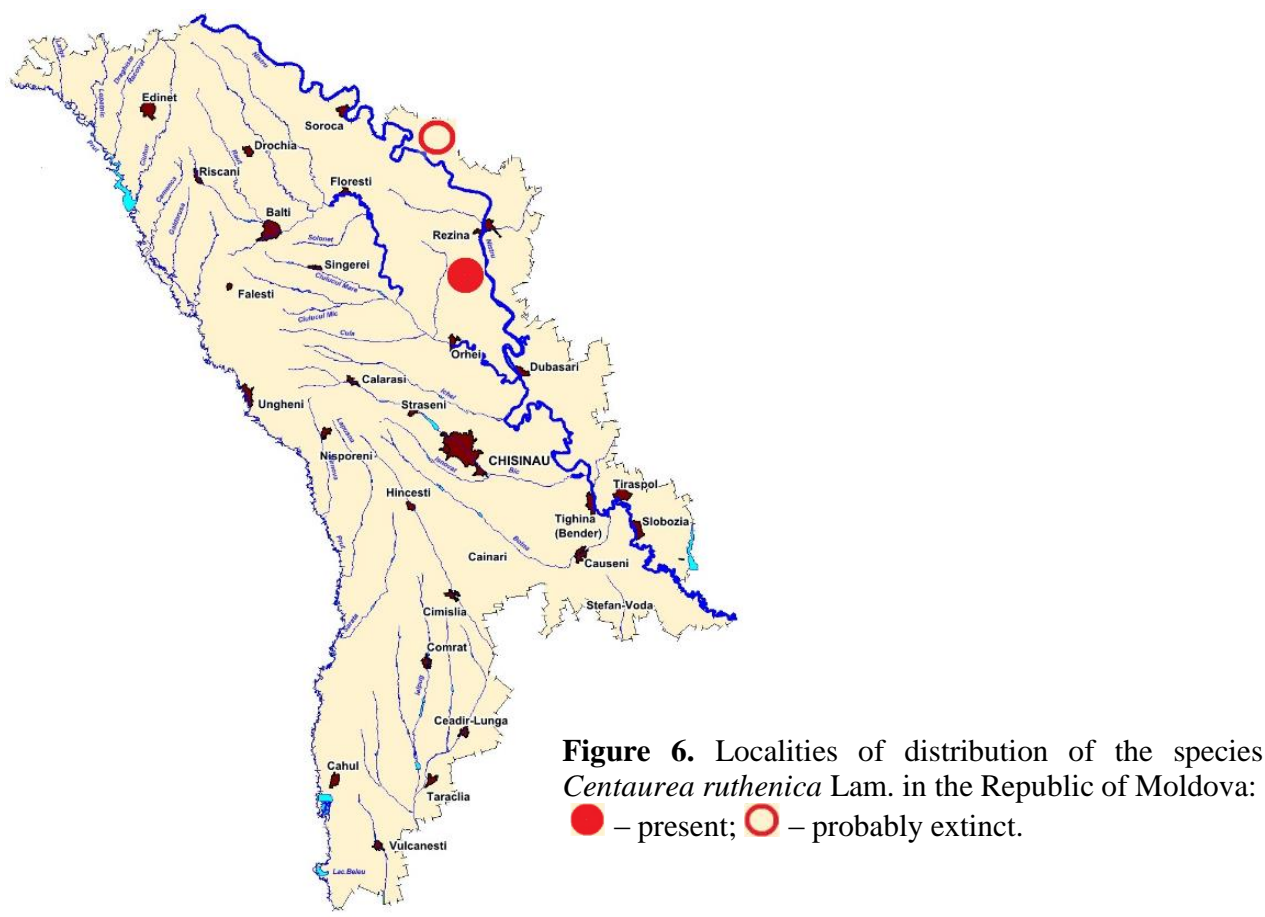




\section{Conclusions}

Centaurea ruthenica Lam., under the climatic conditions of the Republic of Moldova, is a rare xerophytic species and we propose to include it in the List of species protected by the state and in the Red Book of the Republic of Moldova, in the Critically Endangered (CR) category. habitat.

We suggest to avoid collecting specimens of this species for herbaria from its natural

The research was supported by the NARD through the project "Research and conservation of vascular flora and macromycobiota of the Republic of Moldova", 20.80009.7007.22 (contract No. 71/PS/2020).

\section{References}

AGHABABYAN M. V. 2008. Rhaponticoides ruthenica (Lam.) M. V. Agab. et Greuter, pp. 299-300. In: TAKHTAJAN A. L. (eds.) Caucasian flora conspectus. Saint-Petersburg - Moscow: KMK Scientific Press. 3(1): 469 pp. (In Russian).

Compositae Working Group (CWG). 2021. Global Compositae Database. Rhaponticoides ruthenica (Lam.) M. V. Agab. \& Greuter. Accessed at: https://www.compositae.org/aphia.php?p=taxdetails\&id=1248188 on 2021 $12-08$

CZEREPANOV S. K. 1994. Centaurea ruthenica Lam., p. 270. In: TZVELEV N. N. (eds.) Flora partis europaeae URSS. Petropoli: Nauka. 7: 319 pp. (In Russian).

DOBROCZAJEVA D. N. 1999. Centaurea ruthenica Lam., p. 355. In: PROKUDIN YU. N. (eds.). Opredelitel' vysših rastenij Ukrainy. Kiev: Fitosotziotzentr, izd. 2: 854 pp. (In Russian).

DOSTÁL J. 1976. Centaurea ruthenica Lam., p. 263. In: TUTIN T. G. \& al. (eds.). Flora Europaea. Plantaginaceae to Compositae (and Rubiaceae). Cambridge: Cambridge University Press, Vol. 4: 505 pp.

IUCN. 2001. IUCN Red List Categories and Criteria: Version 3.1. IUCN Species Survival Commission. IUCN, Gland, Switzerland.

IUCN. 2003.Guidelines for Application of IUCN Red List Criteria at Regional Levels: Version 3.0. IUCN Species Survival Commission. IUCN, Gland, Switzerland and Cambridge. UK. ii $+26 \mathrm{pp}$.

NEGREAN G. \& DIHORU G. 2009. Centaurea ruthenica Lam., p. 150-152. In: DIHORU G. \& NEGREAN G. Cartea roșie a plantelor vasculare din România. București: Edit. Academiei Române, 630 pp.

Plantarium. 2007-2021. Rhaponticoides ruthenica (Lam.) M. V. Agab. \& Greuter // Plants and lichens of Russia and neighboring countries: open online galleries and plant identification guide. https://www.plantarium.ru/lang/en/page/view/item/91017.html

SÂRBU I., ȘTEFAN N. \& OPREA A. 2013. Plante vasculare din România. Determinator ilustrat de teren. București: Edit. Victor B Victor: 1317 pp.

SCHMALHAUZEN I. F. 1886. Flora jugo-zapadnoj Rossii, gubernij: Kievskoj, Volynskoj, Podolskoj, Poltavskoj, Černigovskoj i smejnyh mestnostej. Rukovodstvo dlja opredelenja semenyh i sporovyh rastenij. Kiev: Tipogr. S.V. Kulgenko. 783 pp. (In Russian).

SCHMALHAUZEN I. F. 1897. Flora Srednej i Jugnoj Rossii, Kryma i Severnovo Kavkaza. Kiev. Vol. II, 752 pp. (In Russian).

TZVELEV N. N. 1963. Centaurea ruthenica Lam., p. 380. In: BOBROV E. G. \& CZEREPANOV S. K. (eds.). Flora URSS. Mosqua - Leningrad: Editio Academieae Scientiarum URSS, vol. 28, 654 pp. (In Russian).

\section{How to cite this article:}

PÎNZARU P. 2021. Centaurea ruthenica Lam. (Asteraceae Dumort.) in the flora of the Republic of Moldova. J. Plant Develop. 28: 169-174. https://doi.org/10.47743/jpd.2021.28.1.885 